\title{
Helmut K. Anheier and Stefan Toepler (eds.), The Routledge Companion to Nonprofit Management
}

\author{
Routledge, London and New York, 2020, 531 pp, Bibliography, Index, \$227 (hardcover), \\ $\$ 51,95$ (Kindle)
}

\author{
Annette $\operatorname{Zimmer}^{1}$ (D)
}

Accepted: 18 November 2020/Published online: 2 December 2020

(C) The Author(s) 2020

The editors of the Routledge Companion to Nonprofit Management are distinguished scholars in the field of nonprofit management and governance with an outstanding record of publications and a world-wide network of social scientists with whom they have been co-operating in numerous research projects, international conferences and panel discussions focusing on civil society and/or the nonprofit sector since the early 1990s. They also are highly experienced teachers in the social sciences and in nonprofit studies. Against this background, the most recent handbook on nonprofit management addresses a broad audience of scholars, and students of nonprofit organizations as well as policy experts and political advisors with an interest in the sector.

Organized in six chapter, each of which consists of four to five articles of about 20 pages each, the volume provides an encompassing and up-to-date overview of the current state of the art of nonprofit management for an international audience. This purpose is clearly indicated in the introductory. The handbook aims at strengthening the field against the background of both a significant changed organizational environment in terms of nonprofit-government relations, and simultaneously an increased importance of nonprofits for the provision of (public) goods and service world-wide. A key feature of the handbook relates to the specificity of nonprofits that are "not closed systems, but highly dependent on their environments" in terms of

Book review editor: Marc Jegers.

Annette Zimmer

zimmean@uni-muenster.de

1 Institute for Political Science, Münster University, Münster, Germany traditions, organizational cultures and legal systems. Accordingly, the handbook starts out outlining the Management Context (Part I, pp. 9-136) of nonprofits in a global, albeit regional differentiated perspective. Although, Part I of the volume covers a broad spectrum of regions and countries, which ranges from the Anglo-Saxon world to Europe, Asia, Africa and the Middle East, "change" constitutes the overarching theme that runs through each article. In the words of Susan Philipps and her illustration of the management context for nonprofits in the Anglo-Saxon countries "the unfolding developments in regulation, philanthropy and service delivery ..... are signs of major shifts, akin to a tectonic scale, in the relationships to governments and society at large" (p. 23). According to her judgment, the overall trend of nonprofits becoming more and more business-like translates into the question as to when a nonprofit does no longer qualify as a nonprofit. At the same time, she draws our attention to the "fading of the nonprofit sector" (p. 23) from government's agendas in the West where nonprofit organizations have ceased to be prime partners of government in policy and politics, particularly in the area of social service provision. Whereas in other parts of the world, such as in Russia, in Asia, and particularly in China as well as in Eastern Europe, the sector has developed into a "major component of the national economy" (p. 65), and supported by government grants nonprofits have become appreciated partners of welfare policies. Simultaneously in these regions, nonprofits, particularly those engaged in lobbying and advocacy activities, are faced with increased scrutiny and tough regulatory procedures up to straightforward repression enacted by governments. Indeed wherever you are, nonprofit management has become a very difficult task and asks for skillful maneuvering through complex environments, littered with pitfalls. How to avoid management 
failures and how to steer nonprofit organizations best is addressed in the following parts II to $\mathrm{V}$ of the volume with a focus on strategy (Part II: Leading and planning), managing internal (Part III) and external relations (Part IV) and financing (Part V: Funding sources). It has to be highlighted that the handbook pays special attention to the specificity of nonprofits by underlining the importance of values and virtues as codes of conduct for nonprofit managers (p. 165) by referring to volunteer management ( $p$. 278) as a technique of pivotal importance for nonprofits, and by characterizing advocacy and lobbying as a core function and not as a fringe activity of nonprofits (p. 344). The final part of the handbook-Part VI: The social enterprise space (pp. 455-530)—pays tribute to the "hybridization" of nonprofits in terms of an increased rapprochement of the organizations towards the market and its specific logics of efficiency and competition that in certain cases might provide avenues for social innovations.

There are many reasons as to why to make use of the handbook. The international perspective counts most prominently. Unlike many other handbooks, the Companion to Nonprofit Management speaks indeed to nonprofit managers working in very different contexts all over the world. Also, the articles of this handbook provide insights not only for nonprofit professionals with a background in management, but they equally address topics that are of interest and concern for scholars of political science, and/or public administration. However, the broad spectrum covered by the handbook brings also some problems that are related to the scope and diversity of the regions portrayed as contextual environments of nonprofit management in Part I of the volume. A case in point is the chapter on Asia (pp. 73-90) that covers a continent with an extreme diversity of countries. The majority of the world's population lives in India and China; both countries look back upon a remarkable story of economic and nonprofit growth. However, these two Asian giants are not very well covered by the handbook. The same holds true for the core management parts of the handbook. Each chapter, indeed, tries to take into account that the world is very different and advocacy in, e.g., Russia plays out differently compared to lobbying activities in, e.g., a Western European country. However, the chapters do not go into detail, and do not thoroughly acknowledge the contextual impact on any managerial topic.

Despite this caveat, the handbook edited by Helmut Anheier and Stefan Toepler is indeed a very valuable companion to students and scholars of nonprofit research and management, because it helps to understand the diversity and complexity of the sector, it sheds light on the nexus between the context of the organization and the challenges or potentials, managers of nonprofit organizations are confronted with, in their daily work. Finally, the handbook constitutes an impressive resource for those who are engaged in nonprofit research because almost all the articles of the volume point to urgent issues that might be either related to the changed economic and political environment of nonprofits or to changes of the very nature of nonprofits itself. As "hybrid organizations, nonprofits are working almost as proxies of either government entities or commercial enterprises, and hence are endangered of losing their identity.

Funding Open Access funding enabled and organized by Projekt DEAL..

Open Access This article is licensed under a Creative Commons Attribution 4.0 International License, which permits use, sharing, adaptation, distribution and reproduction in any medium or format, as long as you give appropriate credit to the original author(s) and the source, provide a link to the Creative Commons licence, and indicate if changes were made. The images or other third party material in this article are included in the article's Creative Commons licence, unless indicated otherwise in a credit line to the material. If material is not included in the article's Creative Commons licence and your intended use is not permitted by statutory regulation or exceeds the permitted use, you will need to obtain permission directly from the copyright holder. To view a copy of this licence, visit http://creativecommons. org/licenses/by/4.0/.

Publisher's Note Springer Nature remains neutral with regard to jurisdictional claims in published maps and institutional affiliations. 